\title{
Neutral vowels and the autosegmental analysis of Hungarian vowel harmony
}

GEERT E. BOOIJ

\section{Abstract}

In this paper it is shown that the behavior of neutral vowels in Hungarian, i.e. vowels that do not undergo vowel harmony, can be readily accounted for in an autosegmental analysis of vowel harmony. This analysis also allows for an insightful account of lexical exceptions to Hungarian vowel harmony ( $a$ much debated issue) without making use of absolute neutralization and ad hoc word-internal grammatical boundaries.

\section{Introduction}

The well-known phenomenon of vowel harmony in Hungarian seems to be a good candidate for an autosegmental analysis. ${ }^{1}$ Such an analysis has been proposed by Clements (1977). However, it is criticized by Anderson (1980) and Vago (1980b). Their main objection to the autosegmental theory of vowel harmony is that it is not able to give a proper account of the so-called neutral vowels, i.e. vowels which do not participate in the harmony.

It is the aim of this paper to show that the problem of neutral vowels can be solved in an insightful way, and thus the autosegmental analysis of vowel harmony can be maintained. In the first section, I give a short survey of the relevant facts of Hungarian. Section 2 analyzes the problem of neutral vowels and proposes a solution to that problem. Finally, section 3 shows that the analysis argued for in section 2 can also handle the various kinds of exceptions to vowel harmony in Hungarian quite nicely.

\section{Hungarian vowel harmony}

The following underlying vowels can be assumed for Hungarian (Vago 1980a: 2): 


\begin{tabular}{|c|c|c|c|c|}
\hline \multicolumn{2}{|c|}{ short vowels: } & \multicolumn{2}{|c|}{ long vowels: } & \\
\hline front & back & front & back & \\
\hline $\mathrm{i} \quad \ddot{\mathrm{u}}$ & $\mathrm{u}$ & i ü & ú & high \\
\hline & $\begin{array}{l}o \\
a(=[0])\end{array}$ & é ő & á ó & $\begin{array}{l}\text { mid } \\
\text { low }\end{array}$ \\
\hline
\end{tabular}

In standard Hungarian the short $/ \mathrm{a} /$ is realized as [0], and the short $/ \mathrm{e} /$ differs in quality from the long /é/: phonetically, it is an $[\varepsilon]$.

All vowels participate in a backness harmony except $i, i$ and $\dot{e}$, the socalled neutral vowels. ${ }^{2}$ That is, except for the neutral vowels, all vowels in a (phonological) word are either [-back] or [+back]. The following examples illustrate this:

(2) a. ölelés 'embracement'

hajó 'ship'

b. ölelés-nek dative sg. hajó-nak dative sg.

The roots in (2a) contain either front or back vowels, and the vowel of the dative suffix nek/nak is either [-back] or [+back], in harmony with the backness specification of the root vowels.

In an autosegmental analysis of this vowel harmony the roots can be lexically specified with an autosegment [-B(ack)] or [+B(ack)], which is associated with the vowels of the root by means of the association convention. This implies that the vowels in the segmental core are archisegments, i.e. they are underspecified since they do not contain a specification for the feature [back]. The same holds for alternating suffixes like nek/nak. Archisegments will be represented by capitals. Thus, the phonetic form of the examples in ( $2 b$ ) will be derived as follows:

a. $[-B]$

OlElÉs-nAk

b. $[+\mathrm{B}]$

hajÓ-nAk $\rightarrow$

Association

$\rightarrow$

[-B]
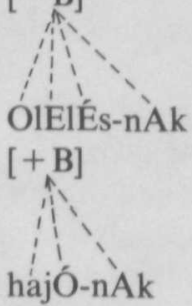

The domain of vowel harmony in Hungarian, as in most languages, is the phonological word. Since compounds consist of at least two phonological words, they may contain 'disharmonic' vowels; for instance, ${ }^{3}$

$$
\begin{array}{ll}
\text { Buda }+ \text { Pest } & \rightarrow \text { Budapest } \\
\text { könyv 'book' + tár 'collection' } \rightarrow \text { könyvtár 'library' }
\end{array}
$$


The same holds for verb + particle combinations:

(5) át 'over' + jön 'come' $\rightarrow$ átjön 'come over'

\section{The neutral vowels}

The neutral vowels $i, i$, and $\dot{e}$ co-occur with both front and back vowels within a root. Moreover, they do not determine the backness specification of a following vowel. This is illustrated in (6) and (7):

(6)

tányér 'plate' tányér-nak (dat.)
radír 'eraser' $\quad$ radír-nak (dat.)
$\begin{array}{ll}\text { béka 'frog' } & \text { béká-nak (dat.) } \\ \text { root: } & \text { diminutive form: }\end{array}$

Erzsébet

Klára
Erzsi

Klári

$$
\begin{aligned}
& \text { tányér-tól (abl.) } \\
& \text { radír-tól (abl.) } \\
& \text { béká-tól (abl.) }
\end{aligned}
$$

+ endearment suffix $-k e / k a$ :

Erzsike

Klárika

Clements (1977) proposed to account for these neutral vowels by first associating all vowels with the autosegment and subsequently applying a rule that introduces the autosegment $[-\mathrm{B}]$ for nonlow, nonround vowels; for instance,

(8) $[+\mathrm{B}]$

$$
\mathrm{klÁr}+\mathrm{I}+\mathrm{kA}
$$

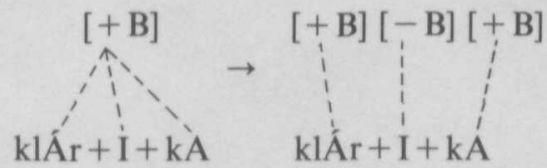

Such an analysis is possible because Hungarian happens to have no surface nonlow, nonround vowels which are [+ back]. Therefore, one can assume a rule that turns all underlying [ + back] nonlow, nonround vowels into their [- back] counterparts.

A different approach to neutral vowels is suggested by Clements and Sezer (1982: 217). In this paper they propose the following parameters for harmony processes:

(9) a. The class of P-segments (melody units) which constitute the autosegmentally represented harmony features;

b. The class of P-bearing units (melody-bearing units) defined as the class of units to which P-segments are associated under the universal well-formedness conditions;

c. The (possibly null) class of opaque segments, defined as those which are underlyingly associated with a P-segment;

d. The (possibly null) class of transparent segments which must be formally excluded from the class of P-bearing units;

e. The domain within which the well-formedness conditions initially apply. 
In this framework, parameter (d) will be specified as [i, i, é] for Hungarian, and thus these segments will not be associated with the autosegment $[+/-\mathrm{B}]$. Consequently, these vowels have to be specified for the feature [back] in the segmental core. This is also pointed out by Clements and Sezer (1982: 218): 'Transparent segments ... receive their feature values by independent specification'. However, they do not go into the question of whether this specification will be present underlyingly or added after the application of the rule of backness harmony. If the latter position is taken, parameter (d) cannot 'see' the difference between a front vowel and its back counterpart. This is no problem in the case of Hungarian, because of the absence of the [+ back] counterparts of the three neutral vowels $/ \mathrm{i}$, $\mathrm{i}$, é/. However, it would be a problem for a language in which a front vowel is neutral with respect to backness harmony but its [+ back] counterpart is not. An analogical reasoning holds for other kinds of harmony.

Such languages do exist, and this is the very reason why Anderson (1980) rejects Clements's autosegmental analysis of Hungarian vowel harmony. Anderson's first example is Khalkha Mongolian. In this language, the vowel $/ \mathrm{i} / \mathrm{is}$ neutral with respect to roundness harmony, but its [+ round] counterpart, the $/ \ddot{\mathrm{u}} /$, is not. That is, in this language we cannot freely associate a [+ round] autosegment with the /i/ because the rounded /i/, [ü], cannot be converted into an [i] later on. Or, to put it in terms of Clements and Sezer (1982): parameter (d) cannot see the difference between an underspecified /i/ and an underspecified / $\mathrm{u} /$ in the segmental core.

Anderson's second example is Finnish, which also features backness harmony in vowels, with $/ \mathrm{i} /$ and $/ \mathrm{e} /$ as neutral vowels. The problem here is that in foreign loans not only /i/ and /e/, but also / $/ \ddot{u} /$ and occasionally even $/ \ddot{0} /$ are treated as neutral vowels, e.g. marttyyrius 'martyrdom' (where $y$ stands for [ü]). Although the vowels /i/ and /e/ do not have [+ back] counterparts, such vowels do exist for $/ \ddot{\mathrm{u}} /$ and $/ \mathrm{o} /: / \mathrm{u} /$ and $/ \mathrm{o} /$, respectively. Therefore, Anderson (1980: 32) draws the following conclusion:

(10) 'This shows that neutral vowels cannot actually be integral parts of harmonic domains with respect to $[ \pm$ back] in Finnish, but rather must be skipped over .... This, in turn, shows that a classical assimilatory treatment is to be preferred for at least some instances of palatal harmony to a prosodic rule of the autosegmental type.'

Although Anderson's insight that neutral vowels must be skipped is correct, this does not necessarily lead to a rejection of the autosegmental analysis of vowel harmony. The autosegmental framework of Clements 
and Sezer (1982) solves the problem of the neutral vowels, provided that the neutral vowels are specified for the relevant feature at the underlying level. Only in this way can the class of segments which are transparent to a harmony process be correctly identified. However, this also implies that parameter (d) can be abolished, if we simply assume that an autosegment $[ \pm F]$ is not associated with segments in the segmental core which have already been specified for $\mathrm{F}$.

The idea that a segment can be specified for a given feature in two ways, either autosegmentally or in the segmental core, can also be found in Poser (1982). Poser assumes the following well-formedness condition for phonological representation (1982: 124):

(11) The well-formedness condition

a. Association lines may not cross.

b. Every segment must be fully specified.

Poser clarifies condition (11b) as follows:

(12) 'Condition [11]b may be satisfied in two ways. First, a segment may be specified for a given feature in the segmental core. Such specifications are available for segments that do not participate in prosodic processes. A segment not specified in the segmental core must obtain its specification by association with an autosegment.'

From (12) we infer that autosegmental specifications do not override specifications in the segmental core. As Poser points out correctly, this theory predicts that disharmonic vowels are of two kinds: 'If they are specified at the segmental core, they will be transparent to the harmony, while if they are specified autosegmentally they will be opaque, that is to say, not only will they fail to undergo the harmony but they will themselves be potential harmony triggers' $(1982: 126){ }^{5}$

This theory implies that the Hungarian vowels $/ \mathrm{i}, \mathrm{i}$, é/ will be lexically specified as $[-$ back $]$ in the segmental core. The generalization that these three vowels are neutral will be expressed by a redundancy rule with respect to the segmental core:

$$
\left[\begin{array}{l}
- \text { round } \\
- \text { low }
\end{array}\right] \rightarrow[\text {-back }]
$$

The problems with respect to Khalkha Mongolian and Finnish mentioned by Anderson (1980) and discussed above find a straightforward solution now. The /i/ of Khalkha Mongolian is specified as [-round] in the segmental core. In Finnish, /i/ and /e/ are [- back] in the segmental core, as well as some $/ \mathrm{u} / \mathrm{s}$ and $/ \ddot{\mathrm{o}} / \mathrm{s}$ in loanwords. Note that the theory of 
neutral vowels advocated here predicts that a vowel can be neutral in a subset of the words in which this vowel occurs, as is the case with Finnish /ü/ and /ö/, whereas the parameter approach of Clements and Sezer (1982) only admits the possibility of vowels being always neutral (transparent) or always harmonic (P-bearing segments).

Thus, the phonetic representation of Hungarian words with neutral vowels such as Klárika (cf. 8) will be derived as follows:

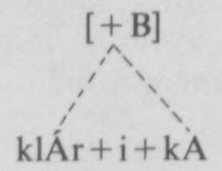

In (14) the vowel / $\mathrm{i} /$ is specified [ - back] in the segmental core, and hence it is not represented with a capital. The autosegment $[+\mathrm{B}]$ is only associated with the two As.

\section{Exceptions to Hungarian vowel harmony}

The problem of the exceptional behavior of certain roots, suffixes, and words with respect to backness harmony in Hungarian and the ensuing descriptive complications are a much debated issue in generative phonology. ${ }^{6}$ An important advantage of the autosegmental analysis of this vowel harmony, in particular the version outlined in the preceding section, is that the different kinds of exception can be accounted for straightforwardly and in such a manner that this harmony can be described as one rule, whereas, for instance, the segmental analysis put forward in Vago (1980a) claims that there are two rules of backness harmony, plus certain morpheme structure conditions which also restrict the co-occurrence of front and back vowels.

Battistella (1982: 96-97) provides a useful list of the different kinds of exceptions, which we will make use of.

A first class of exceptions is that of the so-called 'abstract vowel roots', roots with unrounded front vowels $(i, i, e)$ which take only back vowel suffixes, e.g.

$$
\begin{array}{lll}
\text { híd-nak } & \text { *híd-nek } & \text { 'bridge', dat. } \\
\text { cél-tó } & \text { *cél-töl } & \text { 'goal', abl. }
\end{array}
$$

Vago (1976, 1980a) assumes underlying back vowels for these roots. A rule of absolute neutralization converts these back vowels into front ones, after the rules of vowel harmony have applied. In my analysis, roots such as hid and cél will be represented as in (16): 
(16)

$\begin{array}{ll}{[+B]} & {[+B]} \\ \text { hid } & \text { cél }\end{array}$

That is, the root vowels are specified as $[-$ back] in the segmental core. The floating autosegment $[+\mathrm{B}]$ will not get a phonetic realization unless some affix is added, e.g. $-n A k$ or $-t O ́ l$. In the latter case, the autosegment is associated with the underspecified vowel of the suffix, and thus these vowels surface as [+ back] vowels:
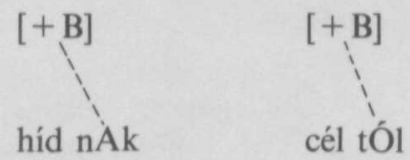

This analysis avoids absolute neutralization and the concomitant extrinsic ordering of the vowel fronting rule after the rule(s) of vowel harmony.

A second class of exceptions is that of loanwords such as soför 'chauffeur' and amöba 'amoeba'. Here, the final vowel of the root determines the quality of the suffix vowel:

$$
\begin{aligned}
& \text { soför-nel 'chauffeur', adessive } \\
& \text { amőbá-nak 'amoeba', dative }
\end{aligned}
$$

These facts can be accounted for as follows. In soför the root-final vowel is opaque: it is a nonundergoer, blocker, and spreader of harmony. The first vowel of soför can be represented as $\{+$ back $\}$ in the segmental core. Therefore, the autosegment $\{-\mathrm{B}\}$ can be assigned to soför without linking this autosegment to the second vowel in the lexical representation. That is, it is not necessary to consider the /ö/ as an opaque vowel in the technical sense of being linked to the autosegment lexically. In amöba the /o/ will be specified as [- back] in the segmental core, and the root will possess the autosegment $[+\mathrm{B}]$ :

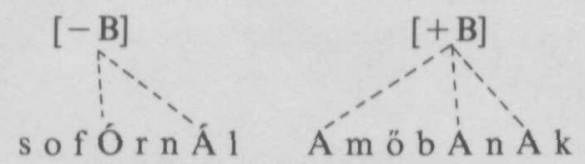

Words which contain roots with neutral vowels require suffixes with front vowels:

$$
\begin{array}{lll}
\text { szín 'color' } & \text { szinnek (dat.) } & \text { szintől (abl.) } \\
\text { szegény 'poor' } & \text { szegénynek (dat.) } & \text { szegénytöl (abl.) }
\end{array}
$$

Here, the neutral vowels seem to be harmonizing after all. This could be expressed by assigning such roots the autosegment $[-B]$, which will spread to the suffix vowels. However, such an approach would violate rule 
(13), which expresses an important generalization with respect to the neutrality of Hungarian vowels. Therefore, some other descriptive mechanism is in order here, that of 'default feature specification': if a segment is not specified for a certain feature, either lexically or by association with an autosegment, it will get the default specification for that feature, [-back] in the case of the feature [back]. This mechanism will provide the suffix vowels of the words in (20) with the correct specification. ${ }^{7}$

The mechanism of default feature specification also enables us to further simplify the description of Hungarian backness harmony: the class of P-segments can be restricted to [+B]. This implies that in the lexical representation of, for example, sofór the autosegment $[-B]$ can be omitted. By restricting the class of P-segments to $[+\mathrm{B}]$ here, we also restrict the kind of exceptional roots which the theory admits: the occurrence of back vowel roots with a floating autosegment [-B], i.e. the occurrence of back vowel roots with front vowel suffixes is excluded.

The third class of disharmonic roots consists of roots with the vowel /e/. We distinguish the following subclasses (cf. Battistella 1982: 97; Beöthy 1983):

a. back vowel $+/ \mathrm{e} /$; takes front vowel suffixes:
József-nél
'Joseph', adessive
október-nél
'October', adessive

b. vacillating roots: roots which take both front vowel and back vowel suffixes:
Ágnes-nál or Ágnes-nél fotel-nak or fotel-nek honvéd-nak or honvéd-nek

\author{
'Agnes', adessive \\ 'armchair', dative \\ 'Hungarian soldier', dative
}

The roots in (21) cannot be assigned an autosegment [+ B], since it would incorrectly spread to the suffix vowel. Therefore, both back and front vowels of the roots in (21) will be specified for backness in the segmental core, and the suffix vowels will become [- back] by default feature specification.

However, there seems to be evidence that the first vowels of these roots have to be associated with an autosegment [+ B], since the diminutives of these roots (with the diminutive suffix $/-\mathrm{i} /$, a neutral vowel) take back vowel suffixes (note that the final part of the roots is deleted):

$$
\begin{array}{ll}
\text { Józs-i-tól 'little Joseph', ablative } \\
\text { Ág-i-tól } & \text { 'little Agnes', ablative }
\end{array}
$$

The backness of the vowel of the ablative suffix in (23) is predicted, if an autosegment $[+B]$ of the root can spread to the suffix vowel. However, 
this would also imply that the /e/s in the final syllables of József and október must be lexically associated with an autosegment [-B], i.e. they are opaque vowels: if we specified these vowels as [-back] in the segmental core, the $[+\mathrm{B}]$ autosegment of the first vowel(s) of the root would incorrectly spread to the suffix vowels of the words in (21).

All these complications disappear if we assign an autosegment [ $+B]$ to the truncated roots Józs and Ág only, not to József and Ágnes. This is a fairly natural assumption: if we allow for the autosegment $[+\mathrm{B}]$ only, it is only the feature [ + back] of loanword vowels that can be reinterpreted as an autosegment. Since these truncated roots are monosyllabic, and therefore harmonic by definition, they readily lend themselves to this autosegmentalization of the feature [+ back]. Summarizing, I assume separate lexical entries for truncated roots such as Józs and $\hat{A} g$, with an autosegmentalized feature [+B]. Consequently, we do not need the autosegment $[-\mathrm{B}]$ nor opaque vowels.

Roots like Ágnes and honvéd must be assigned dual lexical representations: in one representation the root is provided with an autosegment [+B] which spreads to the first vowel and the suffix (hence Ágnes-nál); in the other one the first vowel is specified as [+ back] in the segmental core, and thus we derive Ágnes-nél by default feature specification.

The existence of vacillating roots appears to be readily interpretable in the theory outlined here. The theory predicts that in disharmonic roots a back vowel can be represented as [+ back] either in the segmental core or by an autosegment $[+\mathrm{B}]$. Certain disharmonic roots admit both interpretations and thus vacillate between front vowel suffixes and back vowel suffixes.

A number of Hungarian suffixes are also exceptional with respect to vowel harmony in that they do not exhibit harmonic alternation. These so-called invariable suffixes are listed in Vago (1980a: 15). Vago distinguishes four classes:

I. $-n i,-i g,-i n t,-s d i,-c s i,-c i,-i s,-i,-s i,-n y i,-d i k$;

II. -képp(en), -ként, -nként, -ért, -ék, -lék, -dék, -ték, -né, -é;

III. $-u s,-u,-k o \dot{,},-a,-k o r$;

IV. -iroz, -ista, -ìmus, -fikál, -ikus.

The invariability of the suffixes of class I and class II follows from the neutrality of $/ \mathrm{i} /$ and $/ \mathrm{e} /$. By representing these vowels as [-back] in the segmental core, it is correctly predicted that the vowels of following variable suffixes harmonize with the root vowels:

ötöd-ik 'fifth'

hatod-ik 'sixth'

Vajda-né 'wife of Vajda'

Szőké-né 'wife of Szőke' ötöd-ik-től (ablative)

hatod-ik-tól (ablative)

Vajdá-né-nak (dative)

Szőké-né-nek (dative) 
Class III contains monosyllabic back vowel suffixes, class IV contains disyllabic suffixes with a neutral vowel followed by a back vowel. Vago (1980a: 15) points out that vowels in alternating suffixes which follow this back vowel will also be [+ back]. Therefore, Vago assigns a morphological boundary \# to these suffixes. This word boundary will block the propagation of the harmonic feature from the root and indicates the beginning of a new domain of backness harmony, in which the feature [+ back] of the final vowel of the invariable suffix is also assigned to following vowels in that domain.

However, the assumption of a boundary \# for these suffixes is rather ad hoc, and Vago does not provide independent evidence. As a matter of fact, the assumption of \# is rather dubious here, since usually a syllable boundary coincides with a word boundary, but this is not the case for these suffixes.

In the autosegmental framework, we do not have these problems. To see this, let us consider the derivation of the dative form of egyetemista 'university student' (derived from egyetem 'university'). The only thing we have to do is to assign an autosegment $[+\mathrm{B}]$ to the invariable suffix $-i s t A$ :

$$
\text { [+ B] }
$$

\section{[[[EgyEtEm] ist $\mathrm{A}] \mathrm{nAk}]$}

We assume that the association of autosegments and the application of the default feature specification rules take place cyclically. The derivation of egyetemistának then runs as follows:

$$
\begin{aligned}
& 1^{\text {st }} \text { cycle: EgyEtEm } \rightarrow \quad \text { egyetem } \\
& 2^{\text {nd }} \text { cycle: } \quad[+\mathrm{B}] \\
& \text { egyetem + ist } \mathrm{A} \\
& 3^{\text {rd }} \text { cycle: } \quad[+B] \\
& \text { egyetem }+ \text { ist } \mathrm{A}+\mathrm{nAk}
\end{aligned}
$$

This analysis also shows that the notion 'opaque vowel' is not necessary to account for the invariability of the vowels of certain Hungarian suffixes. 


\section{Conclusions}

The autosegmental analysis of Hungarian vowel harmony compares favorably with the different competing segmental analyses. Two major advantages are that the process of vowel harmony can be accounted for by one rule, which applies both in roots and in complex words, ${ }^{8}$ and that the different kinds of exception can be accounted for very simply.

The objections to the autosegmental theory of Hungarian vowel harmony raised by Anderson (1980) can easily be met by considering neutral vowels such as $/ \mathrm{i}, \mathrm{i}, \mathrm{e} /$ as transparent vowels which are specified as [- back] in the segmental core. This also implies that the independent parameter 'transparent vowel' suggested by Clements and Sezer (1982) for the treatment of vowel harmony is not necessary anymore. The fact that in Finnish only certain / $/ \mathrm{u} / \mathrm{s}$ and $/ \ddot{\mathrm{o}} / \mathrm{s}$ are transparent provided independent evidence for the theory of neutral vowels developed in this paper. Finally, opaque vowels can also be dispensed with in the description of Hungarian vowel harmony.

Received 27 November 1984

Department of General Linguistics

Free University

P.O. Box 7161

1007 MC Amsterdam

The Netherlands

\section{Notes}

* I would like to thank Ben Hermans and Robert Vago for the stimulating discussions which I had with them on the subject matter of this paper. Robert Vago has also informed me that he has given up the anti-autosegmental position of Vago (1980b). In Vago (1984) an autosegmental analysis of Hungarian vowel harmony is given, which differs from that in this paper. This paper is part of research project no. LETT 83/7, Faculty of Letters, Free University, Amsterdam.

1. Cf. Poser (1982) for a list of arguments in favor of the autosegmental treatment of vowel harmony.

2. Apart from backness harmony Hungarian also exhibits a restricted kind of roundness harmony in short mid vowels. This kind of harmony will be left out of discussion in this paper.

3. When a compound is suffixed, the specification for backness of the suffix vowel(s) is determined by the backness value of the second root, e.g. látkép 'view' - látképünk 'our view', with the suffix -Unk. That is, kép and -Unk form one phonological word. Thus we note an asymmetry between the morphological and prosodic structure of suffixed compounds:

morphological structure [[[lát][kép]]Unk]

prosodic structure $\quad\left((\text { lát })_{\omega}(\text { képUnk })_{\omega}\right) \quad$ where $\omega=$ phonological word. 
Many languages exhibit this asymmetry between morphological and prosodic structure; cf. Booij and Rubach (1984).

4. Root-final low vowels are lengthened before a suffix; cf. Vago (1980a).

5. This assumption differs from Halle and Vergnaud (1981) where it is assumed that autosegmental specifications override segmental specifications. The idea to account for neutral vowels by specifying the relevant feature in the segmental core can also be found in V. d. Hulst and Smith (1982b). However, they do not draw the conclusion that parameter (d) can be abolished.

6. Cf. Battistella (1982); Jensen (1978); Phelps (1978); Vago (1976, 1978); and Zonneveld (1980).

7. Hermans (1984) also provides evidence for a default feature specification mechanism for Icelandic.

8. Cf. Vago $(1976,1978)$ where it is claimed that with respect to vowel harmony we cannot generalize across roots and derived words, and Ringen $(1977,1978,1980)$ where the position is defended that the vowel harmony rule should be applied to both roots and derived words.

\section{References}

Anderson, S. R. (1980). Problems and perspectives in the description of vowel harmony. In R. M. Vago (ed.), Issues in Vowel Harmony, 1-48. Amsterdam: Benjamins.

Battistella, E. (1982). More on Hungarian vowel harmony. Linguistic Analysis 9, 95-118.

Beöthy, E. (1983). Hongaars. Fundamentele grammatica voor Nederlandstaligen. Muiderberg: Coutinho.

Booij, G. E., and Rubach, J. (1984). Morphological and prosodic domains in lexical phonology. Phonology Yearbook 1, 1-27. Cambridge: Cambridge University Press.

Clements, G. N. (1977). Neutral vowels in Hungarian vowel harmony: an autosegmental interpretation. NELS 7, 49-64.

- , and Sezer, E. (1982). Vowel and consonant disharmony in Turkish. In H. van der Hulst and N. Smith (eds.), The Structure of Phonological Representations, Part 2, 213-256. Dordrecht: Foris.

Halle, M., and Vergnaud, J.-R. (1981). Harmony processes. In W. Klein and W. J. M. Levelt (eds.), Crossing the Boundaries in Linguistics, 1-22. The Hague/Berlin: Mouton.

Hermans, B. (1984). The relation between aspiration and preaspiration in Icelandic. In H. van der Hulst and N. Smith (eds.), Advances in Non-Linear Phonology. Dordrecht: Foris.

Hulst, H. van der, and Smith, N. (eds.) (1982a). The Structure of Phonological Representations, Part 2. Linguistic Models 3. Dordrecht: Foris.

-, and Smith, N. (1982b). Prosodic domains and opaque segments in autosegmental theory. In H. van der Hulst and N. Smith (eds.), The Structure of Phonological Representations, Part 2, 311-336. Dordrecht: Foris.

Jensen, J. T. (1978). Reply to 'Theoretical implications of Hungarian vowel harmony'. Linguistic Inquiry 9, 89-97.

Phelps, E. (1978). Exceptions and vowel harmony in Hungarian. Linguistic Inquiry 9, 98-104.

Poser, W. J. (1982). Phonological representations and action-at-a-distance. In H. van der Hulst and N. Smith (eds.), The Structure of Phonological Representations, Part 2, 121-158. Dordrecht: Foris.

Ringen, C. O. (1977). Vowel harmony: implications for the alternation condition. In W. U. Dressler et al. (eds.), Phonologica 1976. Innsbruck: Institut für Sprachwissenschaft. 
- (1978). Another view of the theoretical implications of Hungarian vowel harmony. Linguistic Inquiry 9, 105-115.

-(1980). A concrete analysis of Hungarian vowel harmony. In R. M. Vago (ed.), Issues in Vowel Harmony, 135-154. Amsterdam: Benjamins.

Vago, R. M. (1976). Theoretical implications of Hungarian vowel harmony. Linguistic Inquiry 7, 243-263.

-(1978). Some controversial questions concerning the description of vowel harmony. Linguistic Inquiry 9, 116-126.

-(1980a). The Sound Pattern of Hungarian. Washington, D.C.: Georgetown University Press.

- (1980b). A critique of suprasegmental theories of vowel harmony. In: R. M. Vago (ed.), Issues in Vowel Harmony, 155-182. Amsterdam: Benjamins.

-(1984). Morpheme-level harmony in a multi-leveled autosegmental framework. Unpublished manuscript, Tel-Aviv University.

-(ed.) (1980). Issues in Vowel Harmony. Proceedings of the CUNY Linguistics Conference on Vowel Harmony, 14 May 1977. Amsterdam: Benjamins.

Zonneveld, W. (1980). Hungarian vowel harmony and the theory of exceptions in generative phonology. Linguistic Analysis 6, 21-39. 